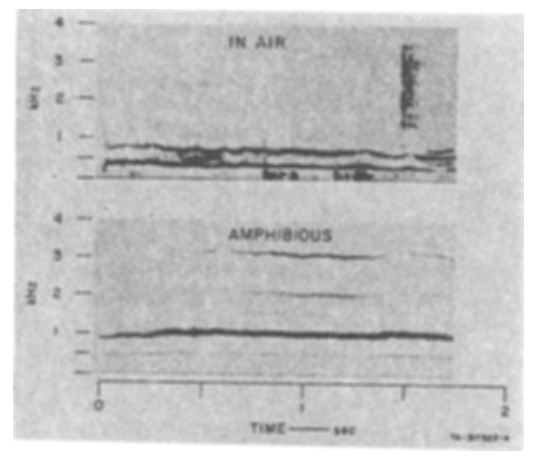

Fig. 4. Sound spectrograms of aerial and amphibious calls by gray seals (analyzing filter bandwidth, $45 \mathrm{~Hz}$ ). The amphibious call was recorded under water. Ignore background noise at the end of the in-air recording.

when the animals were interacting socially. Even in the case of the clicks, the animals were either chasing one another, in physical contact with one another, or orienting toward one another. It should be added that the water the animals were swimming in was extremely clear.

Thus, in the case of the gray seals, as with several other species we have studied, it seems that despite the fact that clicks suggest the possibility of echolocation, these sounds probably play a key role in the social communication systems of these animals. The humming sounds, as well as some of the short pulsed sounds (clicks), are produced in air as well as under water, and are sometimes projected "amphibiously," i.e., both in air and under water simultaneously (see Fig. 4). Thus, like Zalphus, Eumetopias, and Phoca. Halichoerus emit many of the same sounds under water that are emitted in air.

Underwater vocalizations were monitored and recorded by a Channel Industries 275 hydrophone and a Uher $4000-S$ tape recorder at $20 \mathrm{~cm} / \mathrm{sec}$. The tapes were rerecorded on a Uher $4000-\mathrm{S}$ and were analyzed by a Kay 661 audio spectrum analyzer in conjunction with an Ampex tape recorder.

\section{REFERENCES}

CAMERON, A. W. Breeding behavior in a colony of Western Atlantic gray seals. Canadian Journal of Zoology, 1967, 45, 161-173.

EVANS, W. E. Vocalization among marine mammals In W. N. Tavolga (Ed.), Marine bio-acoustics. Vol. 2. New York: Pergamon, 1967. Pp. 159-186.
GENTRY, R. L. Territoriality and reproductive behavior in male Steller sea lions. American Zoologist, 1968, 8, 739 (Abstract).

HEWER, H. R., \& BACKHOUSE, K. M. A preliminary account of a colony of gray seals (Halichoenus grypus Fab.) in the southern Inner Hebrides. Proceedings of the Zoological Society of London, 1960, 134, 157-194.

VORRIS, $K$. The echolocation of marine mammals. In H. T. Anderson (Ed.), The biology of marine mammals. New York: Academic Press, 1969. Pp. 391-423.

ORR, R. T., \& POULTER, T. C. Some observations on reproduction, growth, and social behavior in the Steller sea hon. Proceedings of the Califomia Academy of Science, 1967, 35, 193-225.

POULTER, T. C. Marine mammals. In T. Seboek (Ed.), Animal communication. Bloomington, Ind.: Indiana University Press, 1968 Pp. 405-465.

SCHEFFER, V. B. Seals, sea lions and walruses. $A$ review of the Pinnipedia. Pato Alto, Calif: Stanford University Press, 1958.

SCHEVILL, W. E., WATKINS, W. A., \& RAY, C.
Underwater sounds of pinnipeds. Science, 1963. 141. 50-53.

SCHUSTERMAN, R. J. Perception and determinants of underwater vocalization in the California sea lion. In R. G. Busnel (Ed.), Les systemes sonars animax. Jouy-en-Josas, France: Laboratoire d'Acoustique Animale, 1967. Pp. 535-617.

SCHUSTERMAN, R. J. Experimental laboratory studies of pinniped behavior. In R. J. Harrison, R. C. Hubbard, R. S. Peterson, C. E. Rice, and R. J. Schusterman (Eds.), The behovior and physiology of pinnipeds. New York: Appleton-Century-Crofts, 1968. Pp. 87-171. SCHUSTERMAN, R. J., B BALIET, R. F. Underwater barking by male sea hons (Zalophus californianus). Nature, 1969, 222, 1179-1181.

SCHUSTERMAN, R. J., \& DAWSON, R. G. Barking, dominance and territoriality in male sea lions. Science, 1968, 160, 434-436.

NOTE

1. This research was supported by NSF Grant GB-7039.

\title{
Pentobarbital-induced state-dependent learning of one-way avoidance in mice
}

\section{LAWRENCE BROWNE, ${ }^{2}$ FRED JUDGE, and PHYLLIS KASPER-PANDI, ${ }^{3}$ Sir George Williams University, Montreal, P.Q., Canada}

Four groups of eight albino mice were trained to avoid shock in a one-way avoidance situation. Two groups received pentobarbital sodium during training and two groups received saline. One day after having reached the learning criterion, the mice received one test trial. Prior to the test trial, two groups received the same treatment they had received during training, and two received the other treatment. All 16 mice receiving the same treatment avoided on the test trial, whereas only 4 of the 16 mice receiving the change in treatment successfully avoided. Pentobarbital did not affect the rate of original learning of the one-way avoidance response.

In 1964, Donald Overton found that rats could be trained to make one directional response in a maze to escape shock after having been injected with pentobarbital and the opposite response after having been injected with a placebo. This absence of transfer of training between drug and nondrug states is referred to as "dissociated" or "state-dependent" learning. It has been obtained with a variety of such drugs as chlordiazepoxide (Sachs, Weingarten, \& Klein, 1966), amobarbital (Barry, Etheredge, \& Miller, 1965), phenobarbital (Bindra, Nyman, \& Wise, 1965), and depressant and atropine-like drugs (Overton, 1966).

The purpose of the present study was to produce dissociation of one-way avoidance learning in mice through the use of pentobarbital sodium. Since much of the current literature on drug dissociation involves rats, and since mice are commonly used as Ss in screening drugs, it was considered of interest to demonstrate state-dependent learning in mice.

$$
\text { SUBJECTS }
$$

The Ss were 32 mature male albino mice with an average weight of $26 \mathrm{~g}$. They were housed in groups of eight in a room with an 8 a.m.-10 p.m. light-dark cycle.

\section{APPARATUS}

The one-way avoidance box was made of unpainted plywood, measured $12 \times 6 \times 10$ in., and had a Plexiglas lid. A black center wall with a door divided the box into two equal chambers. The grid floor was wired for shock in the chamber 
containing a 3-W light that served as the CS (conditioned stimulus). The light was located on the wall opposite the center wall, 2 in. from the top of the box. The US (unconditioned stimulus) was a $1-\mathrm{mA}$ unscrambled shock.

\section{PROCEDURE}

The 32 mice were divided into four groups of eight each. Two of the groups served as experimental or "change-state" groups; one of these received pentobarbital then saline (P-S), and one received saline then pentobarbital (S-P). The two control, or "nonchange-state," groups received either pentobarbital (P.P) or saline (S-S) throughout training and testing.

During training, mice in the P-S and P-P groups received $25 \mathrm{mg} / \mathrm{kg}$ of pentobarbital sodium (Nembutal, Abbott) intraperitoneally, and mice in the S.P and $S-S$ groups received sterile saline. When the P-P and P-S Ss were ataxic, yet able to move, they were placed in the avoidance apparatus. The mice normally became ataxic without passing through a stage of complete anesthesia. Reactions to pentobarbital varied both between and within Ss, so that on rare occasions a $S$ might pass through an anesthetized stage before becoming ataxic, or might become rigid, or show no reaction. The dosage was not varied and Ss were trained and tested as usual on occasions when their overt reactions to pentobarbital were abnormal. Mice in the S-S and S-P groups were placed in the apparatus after intervals of $10.20 \mathrm{~min}$ following injection to approximate the times required by the drugged mice to become ataxic. The US was delivered after $10 \mathrm{sec}$ of CS (light) presentation, and both CS and US were response-terminated. Response times were measured with a stopwatch. Ss remained in the safe side of the box for $30 \mathrm{sec}$ after each trial and were then picked up and placed in the shock side of the apparatus. Five trials were given each day. The procedure was repeated until each $S$ reached the criterion of at least 9 out of 10 avoidances summed over two consecutive five-trial sessions, with the first response correct on each session. On the day following the last training session, mice in Groups P-P and S-P were given pentobarbital and mice in Groups S-S and P-S were given saline and were tested for retention. The test trial consisted of one CS-US presentation.

\section{RESULTS}

Pentobarbital itself did not affect the animals' response latencies or the number of trials taken to reach criterion. The mean number of trials to criterion for the mice receiving pentobarbital was 26 , and the control mean was 24 . The performance of the drugged animals was variable, so that the number of shocks received during training (exclusive of criterion trials) ranged from 5 to 26 for the pentobarbital group and 6 to 14 for the saline group. Pentobarbital altered the form of the response. Drugged mice tended to move by means of a rapid rolling crawl, whereas the saline-injected mice ran or jumped.

During the test trial, the change-state groups avoided significantly less often than did the nonchange-state groups (chi square $=16.13$, df $=3, p<.001$ ). All of the nonchange-state mice avoided, whereas, of the change-state groups, only one S-P and three P-S mice successfully avoided shock.

\section{DISCUSSION}

The results indicate that dissociation of learning occurred within the change-state groups. Only 4 out of the 16 mice in the change-state groups avoided shock on the test trial, whereas all 16 mice in the nonchange-state groups avoided. It is possible that some transfer of learning occurred in the change-state groups due to variability of response to pentobarbital. Intraperitoneal injections were used, but it should be noted that it is relatively easy to give intravenous injections to mice. Intravenous drug administration would probably yield less variability.

The effects of the dose of $25 \mathrm{mg} / \mathrm{kg}$ used in the present experiment differed from the effects of the same dose used by Overton (1964) in rats. Our mice normally became ataxic without passing through a stage of anesthesia (loss of righting and escape responses) in contrast to Overton's rats. In general, mice are less sensitive to pentobarbital. The dosage for intraperitoneal administration recommended by Abbott Laboratories for $15-45 \mathrm{~min}$ of anesthesia is $55.0 \mathrm{mg} / \mathrm{kg}$ for mice and $35.2 \mathrm{mg} / \mathrm{kg}$ for rats. The lethal dose for $50 \%$ of the $\mathrm{Ss}$ receiving intraperitoneal injections is $130-150 \mathrm{mg} / \mathrm{kg}$ in mice and $48-75 \mathrm{mg} / \mathrm{kg}$ in rats (Campbell \& Richter, 1967; D. J. Carr, Abbott Laboratories ${ }^{4}$ ). These figures can only serve as a general guide to dosage, since such factors as age (Kalser, Forbes, \& Kunig, 1969), diet (Kato, Oshima, \& Tomizawa, 1968), and sex (Collins, 1969; Kato \& Takanaka, 1967) can alter responsiveness to barbiturates. The use of measures of the drugged state that are more sensitive than ataxia would serve as a good guide to dosage (Wahlström, 1966).

The present procedure required 3-8 days of training compared to the 10-15 days used by Overton $(1964,1966)$. A short training period has the advantage of minimizing complications arising from the development of barbiturate tolerance (Aston, 1966) or hypersensitivity (Conney,
Davison, Gastel, \& Burns, 1960) or withdrawal effects following drug habituation (Leonard, 1967).

\section{REFERENCES}

ASTON, R. Acute tolerance indices for pentobarbital in male and female rats. Journal of Pharmacology \& Experimental Therapy, 1966, 152, 350-353.

BARRY III, H., ETHEREDGE, E. E., \& MILLER, N. E. Counterconditioning and extinction of fear fail to transfer from amobarbital to nondrug state. Psychopharmacologia, 1965, 8, 150-156.

BINDRA, D. B., NYMAN, K., \& WISE, J. Barbiturate-induced dissociation of acquisition and extinction: Role of movement-initiating processes. Journal of Comparative \& Physiological Psychology, 1965, 60, 223-228.

CAMPBELL, D. E. S., \& RICHTER, W. An observational method estimating toxicity and drug actions in mice applied to 68 reference drugs. Acta Pharmacologia et Toxicologia, 1967, 25, 345-363.

COLLINS, T. B. The toxic effects of three different dosages of pentobarbital sodium on the Long-Evans rat. Psychonomic Science, $1969,15,276$.

CONNEY, A. H., DAVISON, C., GASTEL, R., \& BURNS, J. J. Adaptive increases in drug-metabolizing enzymes induced by pentobarbital and other drugs. Journal of Pharmacology \& Experimental Therapy, 1960, $130,1 \cdot 8$.

KALSER, S. C., FORBES, E., \& KUNIG, R. Relation of brain sensitivity and hepatic metabolism of hexobarbitone to dose-response relations in infant and young rats. Journal of Pharmacy \& Pharmacology, 1969, 21, 109-113.

KATO, R., OSHIMA, T., \& TOMIZAWA, S. Toxicity and metabolism of drugs in relation to dietary protein. Japanese Journal of Pharmacology, 1968, 18, 356-366.

KATO, R., \& TAKANAKA, A. Effect of starvation on the in vivo metabolism and effect of drugs in female and male rats. Japanese Journal of Pharmacology, 1967, 17, 208-217.

LEONARD, B. E. The effect of chronic administration of barbiturate sodium on the behavior of the rat. International Journal of Neuropharmacology, 1967, 6, 63-70.

OVERTON，D. A. State-dependent or "dissociative" learning produced with pentobarbital. Journal of Comparative \& Physiological Psychology, 1964, 57, 3-12.

OVERTON, D. A. State-dependent learning produced by depressant and atropine-like drugs. Psychopharmacologia, 1966, 10, 6-31.

SACHS, E., WEINGARTEN, M., \& KLEIN, N. W., JR. Effects of chlordiazepoxide on the acquisition of avoidance learning and its transfer to the normal state and other drug conditions. Psychopharmacologia, 1966, 9, 17-30.

WAHLSTRÖM, G. Hexobarbitone sleeping time in rats following doses with similar, EEG changes. Acta Pharmacologia et Toxicologia, $1966,24,419-434$. NOTES

1. This experiment was conducted in partial fulfillment of the requirements of the Bachelor's degree.

2. Sent reprint requests to Dr. Jane Stewart, Psychology Department, Sir George Williams University, Montreal, Quebec, Canada.

3. Present address: Rudolf Magnus Institute for Pharmacology, University of Utrecht, Vondellaan 6, Utrecht, The Netherlands.

4. Personal communication, 1969. 